\title{
Changes in behaviour during the inter-nesting period and post-nesting migration for Ascension Island green turtles
}

\author{
G. C. Hays ${ }^{1, *}$, P. Luschi ${ }^{2}$, F. Papi ${ }^{2}$, C. del Seppia ${ }^{3}$, R. Marsh ${ }^{4}$ \\ ${ }^{1}$ School of Biological Sciences, University of Wales Swansea, Singleton Park, Swansea SA2 8PP, Wales, UK \\ ${ }^{2}$ Dipartimento di Etologia, Ecologia, Evoluzione, University of Pisa, Via A. Volta 6, 56126 Pisa, Italy \\ ${ }^{3}$ Centro di Studio per la Faunistica ed Ecologia Tropicali del CNR, Via Romana 17, 50125 Firenze, Italy \\ ${ }^{4}$ James Rennel Division, Southampton Oceanography Center, Empress Dock, Southampton SO14 3ZH, United Kingdom
}

\begin{abstract}
Satellite transmitters were attached to green turtles Chelonia mydas while they were nesting on Ascension Island in the South Atlantic $\left(7^{\circ} 57^{\prime} \mathrm{S}, 14^{\circ} 22^{\prime} \mathrm{W}\right)$ and individuals were subsequently monitored during the inter-nesting period and the post-nesting migration to Brazil. During the inter-nesting period, data from the transmitters suggested that turtles generally stayed within $5 \mathrm{~km}$ of the nesting beach on which they had originally been observed. During both the inter-nesting period and migration, turtles were submerged the vast majority (>95\%) of the time, suggesting that they neither basked at the surface nor drifted passively during migration to any great extent. There was a clear dichotomy in submergence behaviour, with submergences tending to be of short duration during postnesting migration (mean $=7.3 \mathrm{~min}, 3318 \mathrm{~h}$ of data from 5 individuals) and of longer duration during the inter-nesting period (mean $=22.1 \mathrm{~min}, 714 \mathrm{~h}$ of data from 5 different individuals). As submergence duration is generally linked to activity levels in sea turtles, this pattern suggests that turtles were comparatively inactive during the inter-nesting period and comparatively active during migration. During both the inter-nesting period and the post-nesting migration, diel submergence patterns were detected with dive duration tending to be longer at night. As the turtles migrated WSW from Ascension Island there was a reduction in their speed of travel. A numerical model of the near-surface currents suggested that this reduction was associated with the weakening of the WSW flow of the prevailing South Atlantic Equatorial Current.
\end{abstract}

KEY WORDS: Green turtle $\cdot$ Chelonia mydas $\cdot$ Satellite tracking $\cdot$ Submergence $\cdot$ Ascension Island

\section{INTRODUCTION}

It has historically been very difficult to study the movements of marine animals over extended temporal and spatial scales because of the logistical problems of following individuals. As a consequence, studies of marine animal movements have traditionally been limited to short-term tracking efforts of a few days or mark-recapture studies. Satellite tracking using the Argos system has, however, provided a tool for exam-

•E-mail: g.hays@swan.ac.uk ining long-distance movements. Over the last decade the increasing miniaturisation and reliability of transmitters and improvements in the location system have started to allow large-scale movements to be accurately charted. For example, satellite tracking has been used to record the movements of penguins (Jouventin et al. 1994, Hull et al. 1997), albatrosses (Jouventin \& Weimerskirch 1990), narwhals (Dietz \& Heidejorgensen 1995), porpoises (Read \& Westgate 1997), seals (McConnell \& Fedak 1996) and right whales (Mate et al. 1997).

There has also been extensive satellite tracking of sea turtles (e.g. Renaud \& Carpenter 1994, Plotkin et 
al. 1995, Gitschlag 1996) with this method being used, most spectacularly, to identify the long-distance migrations that several populations undertake at the end of the nesting season (Papi \& Luschi 1996, Luschi et al. 1998). One of the classic examples of such a long-distance post-nesting migration involves the green turtles Chelonia mydas nesting on Ascension Island in the South Atlantic $\left(7^{\circ} 57^{\prime} \mathrm{S}, 14^{\circ} 22^{\prime} \mathrm{W}\right)$. Both conventional tagging of individuals with numbered flipper tags and satellite tracking studies have shown that females nesting on Ascension Island migrate to feeding grounds over $2000 \mathrm{~km}$ away on the coast of South America (Mortimer \& Carr 1987, Luschi et al. 1998). Such a long-distance migration poses severe physiological challenges. This population of green turtles feeds mainly on macroalgae on the South American coast and individuals are thought not to feed either during the migration to and from Ascension Island or during their stay at the island (Carr et al. 1974, Mortimer \& Carr 1987). Consequently, individuals are thought to survive on huge fat reserves laid down at their feeding grounds with, for example, an estimated $37 \mathrm{~kg}$ of fat being required by a $175 \mathrm{~kg}$ adult to complete the migration (Prange 1976). Any energy saved during trans-Atlantic migration or during the inter-nesting period may allow increased investment in either the number or quality of eggs and hence may enhance the reproductive output of females. As such, it might be expected that females will remain as quiescent as possible during the internesting period and that they should optimise their swimming performance during the migration in order to minimise the energetic cost of returning to South America. In marine animals such as turtles (Prange 1976) and seals (Thompson et al. 1993), the minimum cost of transport $\mathrm{lO}_{2}$ consumed per unit distance moved) generally occurs at an intermediate swimming speed where the product of metabolic rate and time to complete the journey is minimal. In this study we used data from satellite transmitters to examine whether this predicted change in behaviour, from quiescence to activity, occurs between the inter-nesting and migration periods for green turtles nesting on Ascension Island.

\section{MATERIALS AND METHODS}

From April to July 1997, satellite transmitters (model ST-14, Telonics Inc.) were attached to female green turtles while they were nesting on Long Beach, Ascension Island, and were subsequently located using the Argos system. This system assigns a level of accuracy to fixes with Classes 3,2 and 1 being the most accurate (generally $<1 \mathrm{~km}$ from the true position) while Classes
$0, A$ and $B$ have undefined accuracy. Transmitters had a pulse repetition frequency of either 50 or $90 \mathrm{~s}$. Details of the attachment procedure and the method of determining the turtles' speed of travel are given in Luschi et al. (1998). In short, transmitters were attached to the carapace with epoxy. When reconstructing the routes followed during migration, we disregarded those fixes of the lower 3 classes which were considered erroneous (33 out of 585 ) because they inferred either a swimming speed exceeding $5 \mathrm{~km} \mathrm{~h}^{-1}$ ( $\mathrm{n}=25$ fixes; this threshold being derived from speed values calculated from Class 1 to 3 locations only) or a swimming direction which differed by more than $90^{\circ}$ from those recorded in the preceding and following $3 \mathrm{~d}$ ( $\mathrm{n}=8$ fixes). Speed values were then calculated on the basis of the distance and time interval between consecutive fixes. Nomenclature for the identity of the tracked turtles follows that used previously (Luschi et al. 1998).

The transmitters were all set up with a duty cycle of 'on continuously', with a saltwater switch to suppress transmissions when the transmitter was submerged. This switch provided information on the number of submergences and the mean duration of submergences, with this information being integrated into $6 \mathrm{~h}$ intervals. The start and stop times for each of these $6 \mathrm{~h}$ intervals were determined by the time that the transmitter was switched on. The minimum time which was logged as a submergence was either $60 \mathrm{~s}$ (Turtles B, C, D and G) or $10 \mathrm{~s}$ (Turtles E, F, H and I), depending on the particular transmitter. Since submergence information could be obtained even when a location was not calculated, we inferred the position of some submergence records by interpolation from adjacent locations. The time spent submerged was calculated for each $6 \mathrm{~h}$ interval by multiplying the mean duration of submergences by the number of submergences.

To assess the turtles' speed of travel in relation to the magnitude of the prevailing ocean currents as they migrated away from Ascension Island, we used a primitive equation general circulation model: the Global Isopycnic Model (GIM, Luschi et al. 1998, Marsh et al. 1998). We used this model previously to show that the WSW current flow from Ascension Island matches the turtles' departure direction during their post-nesting migration (Luschi et al. 1998). Taking the output from Year 30 of GIM (assumed to be sufficiently spun up to assess near-surface currents), we used 'snapshot' layer velocity fields to diagnose Lagrangian trajectories repeating the approach we have used before for the North Atlantic (Hays \& Marsh 1997). The model gave the position of the surface mixed layer, which is typically $25 \mathrm{~m}$ thick, at 1 mo intervals, from which the current speed was determined. 


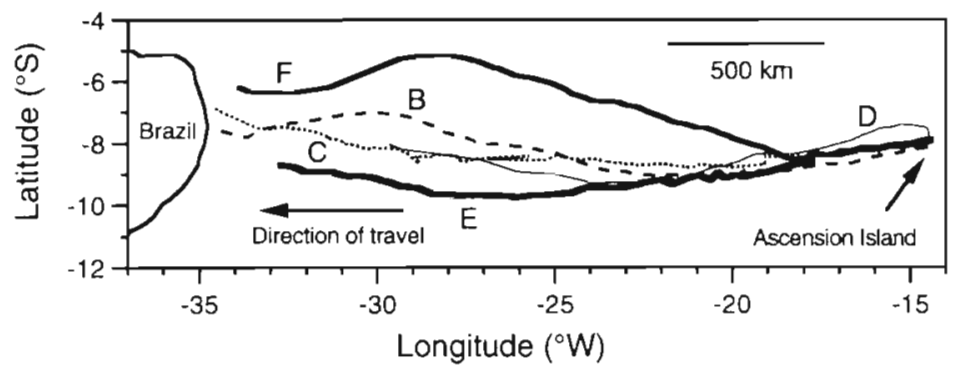

Fig. 1 The routes followed by 5 turtles (Turtles B to F) migrating from Ascension Island to Brazil (from Luschi et al. 1998). The direction of movement is indicated by the arrow

\section{RESULTS}

\section{Movements}

Movements during the post-nesting migration have been reported in detail elsewhere (Luschi et al. 1998). In short, 1 turtle (Turtle A) followed a circuitous route close to Ascension Island while 5 turtles (Turtles B to F) migrated towards Brazil along very consistent paths, especially during the first few hundred $\mathrm{km}$ of their journeys (Fig. 1). Six different turtles (Turtles G to L) subsequently re-nested, as evidenced by locations close to Ascension Island and/or direct observations of re-nesting. Here we compare data from the 5 migrating and 6 inter-nesting turtles.

Locations were obtained relatively infrequently dur-

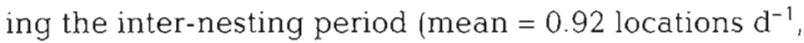
$\mathrm{SE}=0.13, \mathrm{n}=$ a total of $64 \mathrm{~d}$ for which transmitters functioned) and more frequently during migration (mean $=2.49$ locations $\mathrm{d}^{-1}, \mathrm{SE}=0.12, \mathrm{n}=\mathrm{a}$ total of $190 \mathrm{~d}$ for which transmitters functioned), a difference which was highly significant (Mann-Whitney test, $W=$ $28077, p<0.001$ ) (Fig. 2a,b). During both the inter- nesting period and the post-resting migration, locations were dominated by those of the poorest quality (locations Class B) (Table 1). There was considerable variability between the inter-nesting turtles in the rate at which locations were obtained while they were at sea. For example, for Turtle J, no locations were obtained over the entire period of $12 \mathrm{~d}$ before the platform transmitter terminal (PTT) failed, while for Turtles $\mathrm{H}$ and I, 25 and 17 locations were obtained over 12.5
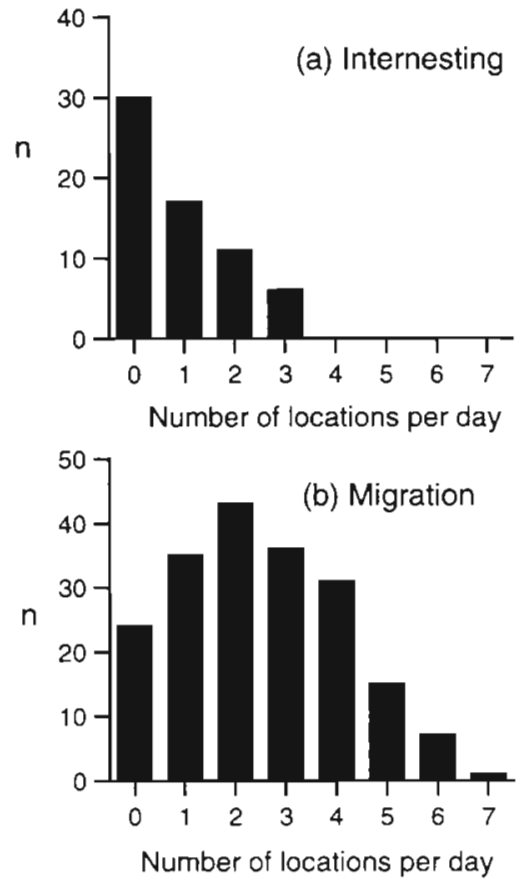

Fig. 2. Number of locations obtained each day during (a) the inter-nesting period and (b) the post-nesting migration

Table 1. Number of locations of the different accuracy classes and the number of submergence records (each recording the mean duration of submergences during individual $6 \mathrm{~h}$ intervals) that were obtained for different turtles during the post-nesting migration (Turtles B to F) and during the inter-nesting period (Turtles $G$ to $\mathrm{L}$ )

\begin{tabular}{|c|c|c|c|c|c|c|c|c|}
\hline \multirow[t]{2}{*}{ PTT id } & \multirow{2}{*}{$\begin{array}{l}\text { Period for which } \\
\text { PTT functioned } \\
\text { (days) }\end{array}$} & \multicolumn{6}{|c|}{ Number of locations } & \multirow{2}{*}{$\begin{array}{l}\text { Submergence } \\
\text { records }\end{array}$} \\
\hline & & 3 & 2 & 1 & 0 & A & B & \\
\hline B & 35 & 5 & 4 & 2 & 2 & 26 & 60 & 105 \\
\hline $\mathrm{C}$ & 39 & 3 & 4 & 1 & 0 & 27 & 66 & 130 \\
\hline $\mathrm{D}$ & 33 & 0 & 2 & 3 & 0 & 19 & 34 & 84 \\
\hline$E$ & 47 & 4 & 5 & 1 & 2 & 28 & 68 & 140 \\
\hline F & 36 & 7 & 11 & 11 & 1 & 24 & 54 & 94 \\
\hline$G$ & 26 & 0 & 0 & 0 & 0 & 0 & 14 & 43 \\
\hline $\mathrm{H}$ & 13 & 0 & 1 & 2 & 0 & 9 & 13 & 23 \\
\hline I & 10 & 0 & 1 & 0 & 0 & 6 & 10 & 24 \\
\hline J & 12 & 0 & 0 & 0 & 0 & 0 & 0 & 24 \\
\hline $\mathrm{K}$ & 3 & 0 & 0 & 0 & 0 & 0 & 3 & 5 \\
\hline $\mathrm{L}$ & 0 & 0 & 0 & 0 & 0 & 0 & 0 & 0 \\
\hline
\end{tabular}


and 8.5 d respectively, i.e. locations for these 2 turtles occurred at a rate of about 2 per day. To assess the value of the Class $A$ and $B$ locations for determining the position of turtles during the inter-nesting period, we examined in detail the data for these latter 2 turtles. For both turtles the majority of locations were centred around an area a few $\mathrm{km}$ west of the nesting beach although a few locations were more distant, being up to $65 \mathrm{~km}$ away (Fig. 3a,b). Certainly, some of the outlying locations were simply inaccurate in reflecting movements by the turtles, since several locations were inland. In order to define the centre of each turtle's inter-nesting range we omitted $35 \%$ of the locations for
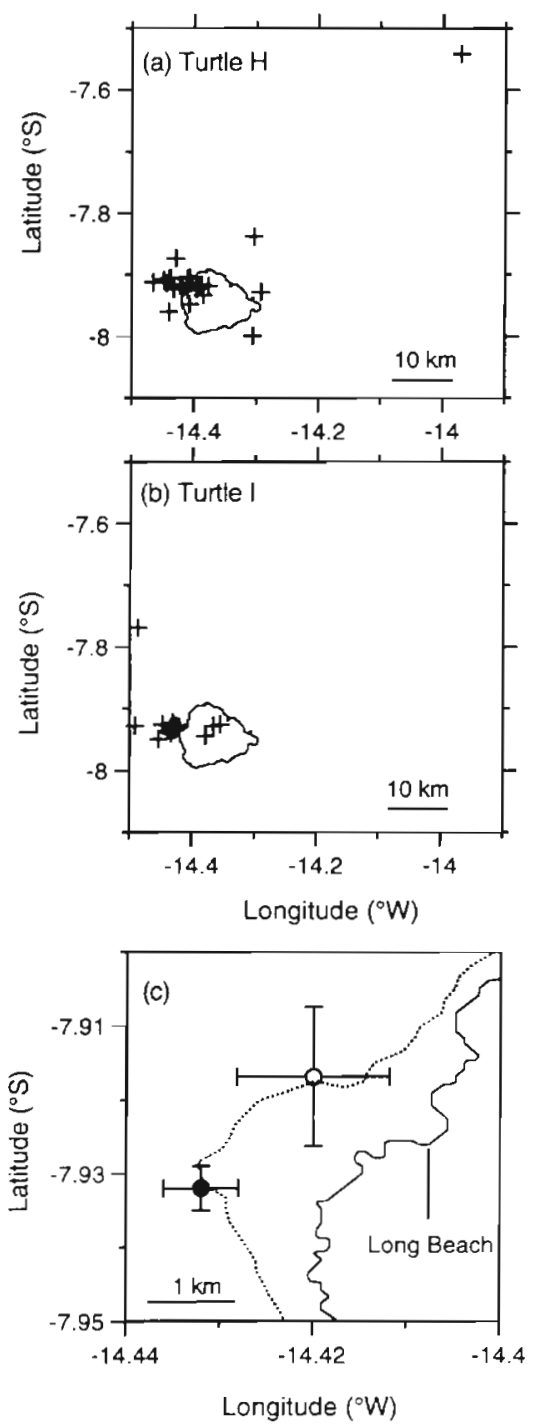

Fig. 3. All the locations obtained for (a) Turtle $H(n=25$ locations) and (b) Turtle I ( $n=17$ locations). (c) The range centre for these 2 turtles during the internesting period (see text for details of calculation) $(0)=$ Turtle $H_{1}(\bullet)=$ Turtle I. Error bars are $\pm 2 \mathrm{SE}$. The dotted line represents the $20 \mathrm{~m}$ depth contour each turtle, retaining the locations that were closest to one another, i.e. those locations that minimised the total inter-sample distance. The positions of these range centres were both within $5 \mathrm{~km}$ of the nesting beach in an area of shallow water that extends west from Ascension Island (Fig. 3c).

\section{Submergence behaviour}

General comparisons between the inter-nesting and migration periods

During both the inter-nesting period and the postnesting migration, turtles spent the vast majority of the time submerged with the mean \% of time spent submerged being $96.0 \%$ during the inter-nesting period $(\mathrm{n}=128,6 \mathrm{~h}$ intervals, $\mathrm{SE}=0.3 \%)$ and $95.4 \%$ during migration ( $n=535,6 \mathrm{~h}$ intervals, $\mathrm{SE}=0.2 \%$ ), a difference which, although small in absolute terms, was significant (Mann-Whitney test, $W=182$ 486, $p=0.01$ ).

During the inter-mesting period turtles tended to conduct long submergences (mean $=22.1 \mathrm{~min}, \mathrm{SE}=$ 1.1 min, $\mathrm{n}=119,6 \mathrm{~h}$ intervals), while during migration, submergences tended to be much shorter (mean = $7.3 \mathrm{~min}, \mathrm{SE}=0.3 \mathrm{~min}, \mathrm{n}=553,6 \mathrm{~h}$ intervals), a difference which was highly significant (Mann-Whitney test, $W=67667, \mathrm{p}<0.001$ ) (Fig. 4).

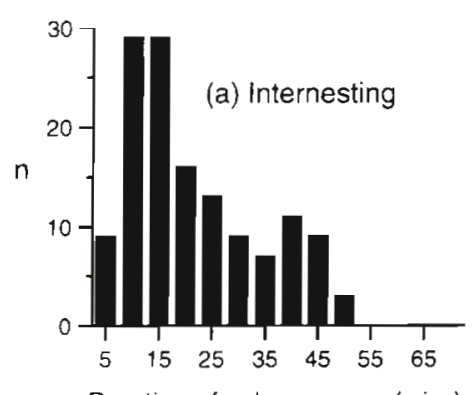

Duration of submergence (mins)

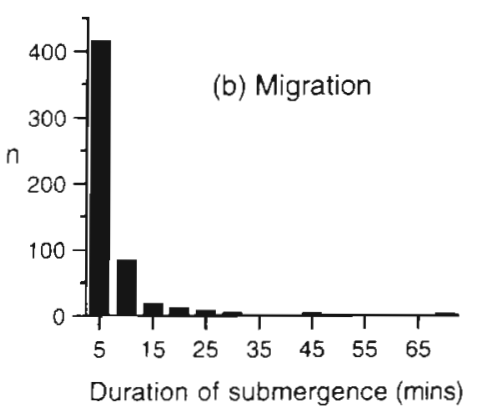

Fig. 4. Mean duration of submergences recorded during individual $6 \mathrm{~h}$ intervals for (a) the inter-nesting period and (b) the postnesting migration 


\section{Diel patterns in submergence behaviour within the inter-nesting period}

During the inter-nesting period, information was received for 3 turtles about submergence behaviour integrated into two $6 \mathrm{~h}$ intervals that occurred predominantly $(>80 \%)$ at night and two $6 \mathrm{~h}$ intervals that occurred predominantly (>80\%) during the day and which covered the majority of the inter-nesting period. For 1 turtle (Turtle G) information was supplied for 2 inter-nesting periods, while for the other 2 turtles (Turtles $\mathrm{H}$ and I) information was supplied for part of a single inter-nesting period. The submergence data for these individuals are shown in Fig. 5 and reveal a few general patterns. In the week immediately after nesting, turtles tended to exhibit longer submergences at night and shorter submergences during the day. As the inter-nesting period progressed, the submergence behaviour during the daytime remained essentially the same. However, the behaviour at night often changed, with shorter submergences being conducted as the date of the subsequent nesting emergence approached. The variation from this general pattern can be gauged with reference to Fig. 5. Turtle G, during its first recorded inter-nesting interval, and Turtles $\mathrm{H}$ and I all conformed to the general pattern of fewer submergences at night at the start of the inter-nesting interval. In contrast, during its second recorded inter-nesting interval, Turtle G showed no diel difference in submergence behaviour, although there was a systematic change in behaviour with longer submergences at the start of the interval and shorter submergences at the end of the interval.

\section{Diel patterns in submergence behaviour during migration}

For 3 of the individuals (Turtles B, C and E) there was a clear and significant diel pattern in the submergence behaviour throughout the migration, with longer submergences at night and shorter submergences during the day (Mann-Whitney test, $W>3959$, $p<0.001$ in all 3 cases). For these 3 individuals the mean duration of nighttime and daytime submergences were: Turtle $\mathrm{B}, 4.9 \mathrm{~min}(\mathrm{SD}=0.4, \mathrm{n}=51,6 \mathrm{~h}$ intervals) and $4.0 \mathrm{~min}(\mathrm{SD}=0.4, \mathrm{n}=54)$; Turtle $\mathrm{C}$, $8.1 \mathrm{~min}$ ( $\mathrm{SD}=2.7, \mathrm{n}=666 \mathrm{~h}$ intervals) and $5.3 \mathrm{~min}$ $(\mathrm{SD}=2.1, \mathrm{n}=64) ;$ Turtle $\mathrm{E}, 15.6 \mathrm{~min}(\mathrm{SD}=1.7, \mathrm{n}=69$, $6 \mathrm{~h}$ intervals) and $5.8 \mathrm{~min}(\mathrm{SD}=0.6, \mathrm{n}=70)$. For the other 2 individuals (Turtles D and F) the most evident pattern in their submergence behaviour during migration was an increase in the duration of submergences as they headed westwards, with long submergences being recorded prior to the cessation of signals from these transmitters (Figs. 6 to 10 ).
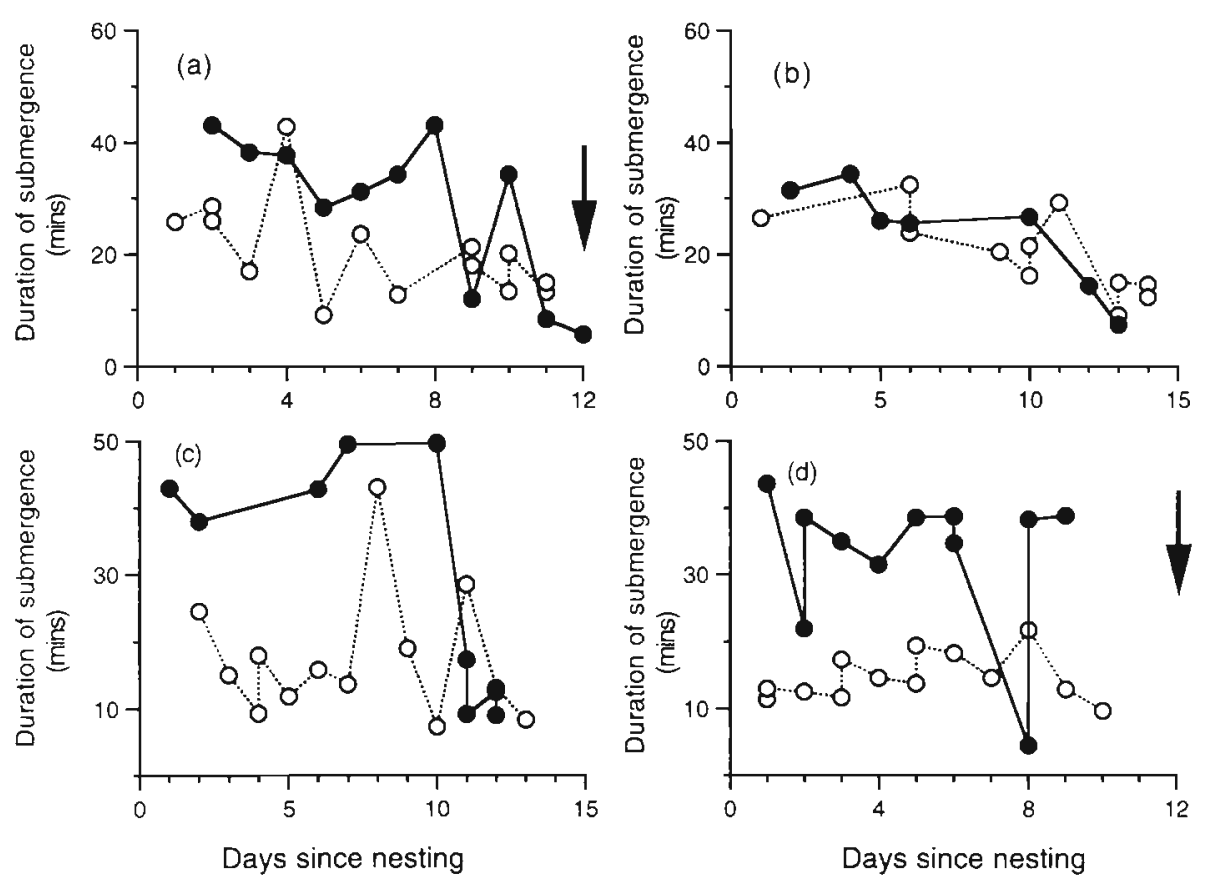

Fig. 5. Mean duration of submergences recorded during individual 6 h periods during the internesting period for (a,b) Turtle G (2 separate internesting periods), (c) Turtle $\mathrm{H}$ and (d) Turtle l. Arrows show when turtles were observed re-nesting. (o) Intervals that were predominantly $(>80 \%)$ during the day, (O) Intervals that were predominantly $(>80 \%)$ during the night 


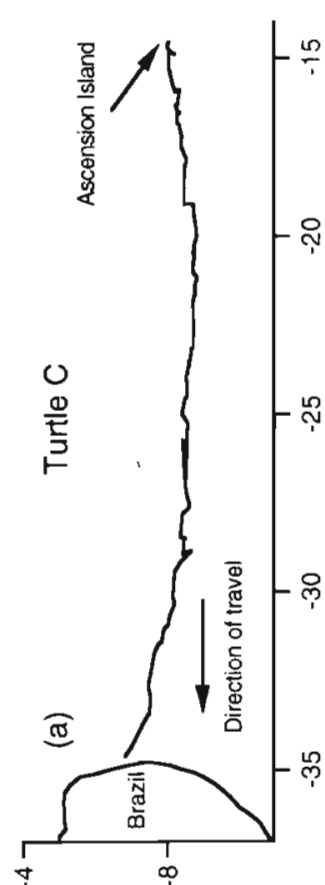

(So) әpпฺฺฺฺอา

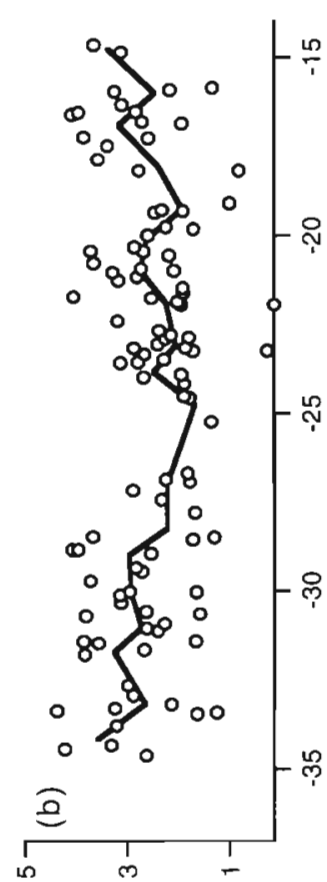

$(1-4 u x)$ paads

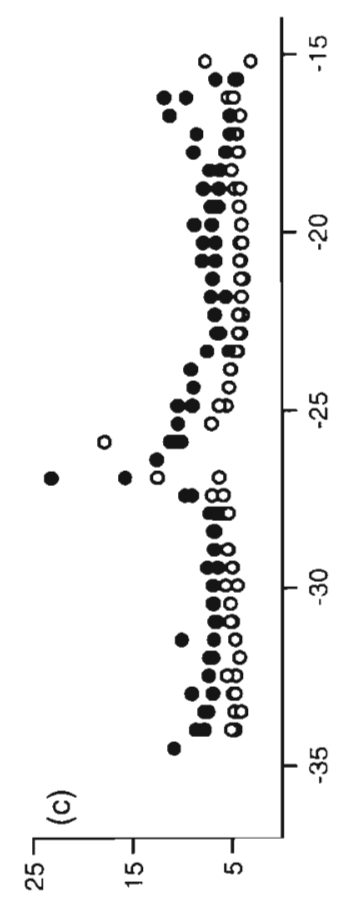

(sulu) әวuә6ょəuqns to uoltesnp ueew

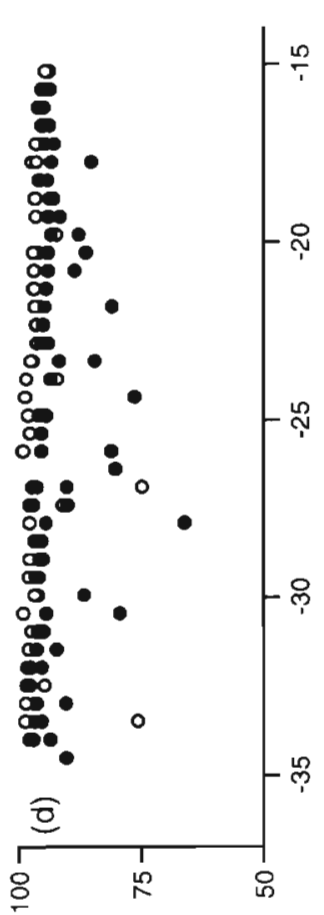

วงuə6jəuqns \%

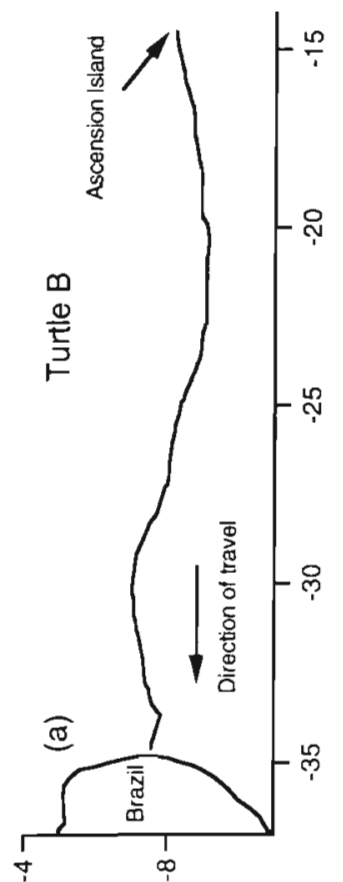

(So) apn!!!e

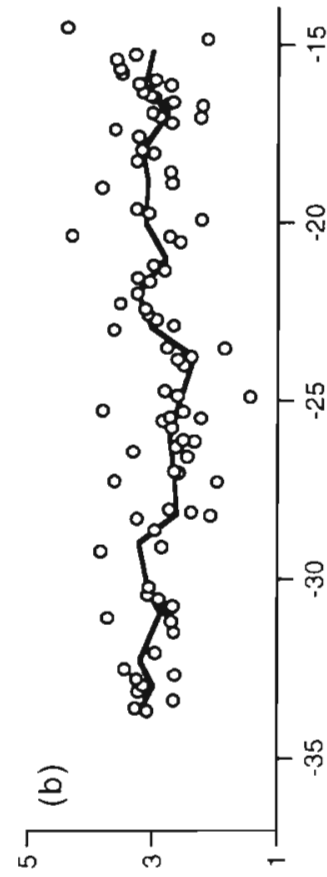

$($ (. 4 'wy) pəəds

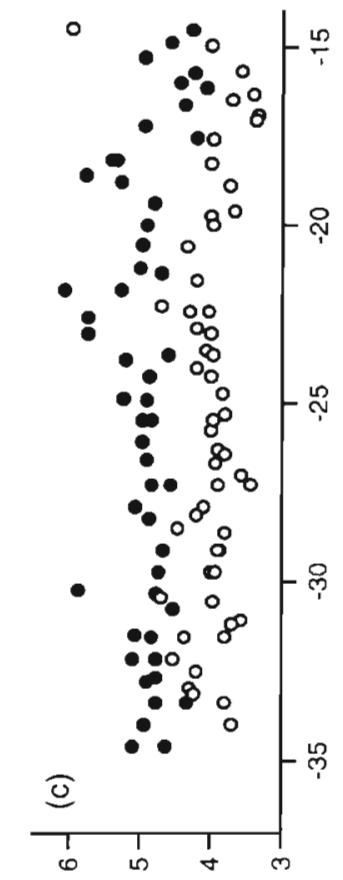

(su!̣) әэuәбృəuqns to uoḷednp ueaw

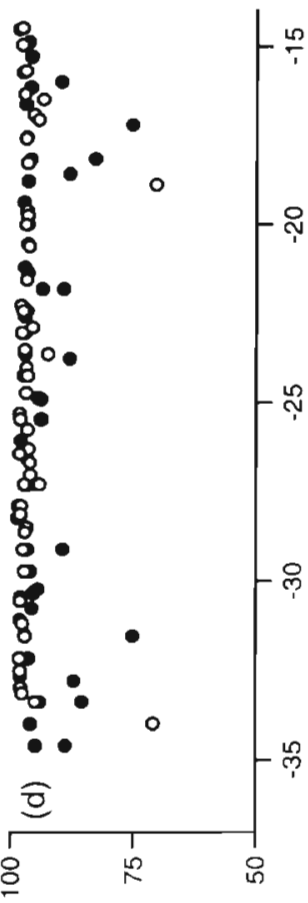

əouə6ıวuนns \%
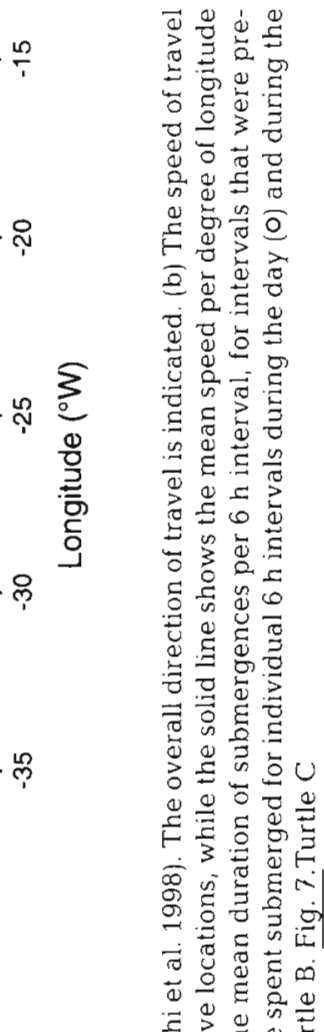

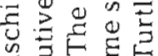

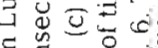

हैं

㲾

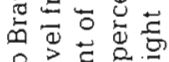

교유

픔

要守

$\S \quad$ 号远

는

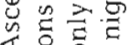

ह $\frac{0}{3} \stackrel{0}{3} \frac{0}{3}$

可焉

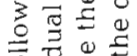

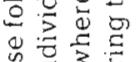

苛要过

至

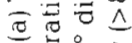

$\therefore$ 무요

ळ $\bar{E} \bar{\Xi}$

○.

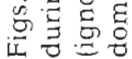




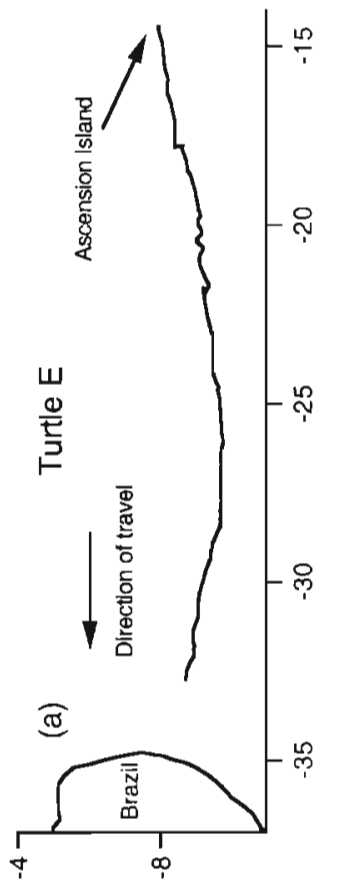

(So) әpnџ!ฺeך

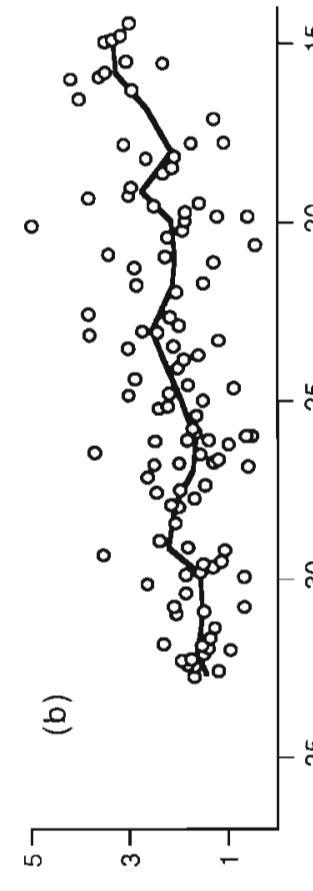

$(1,4 \cdot w y)$ pards

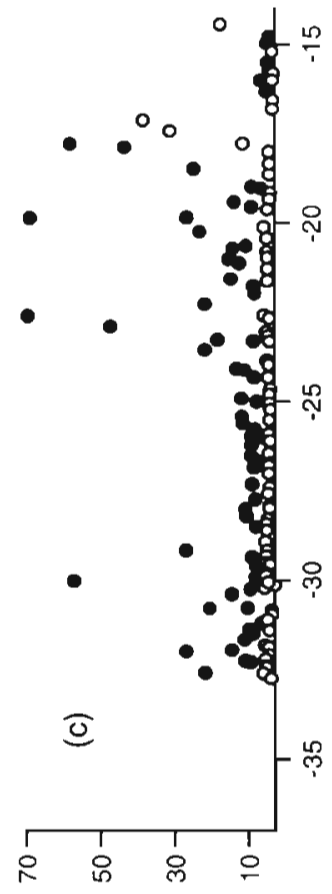

(su!m) әวuə6ృəшqns to uo!tesnp ueaw

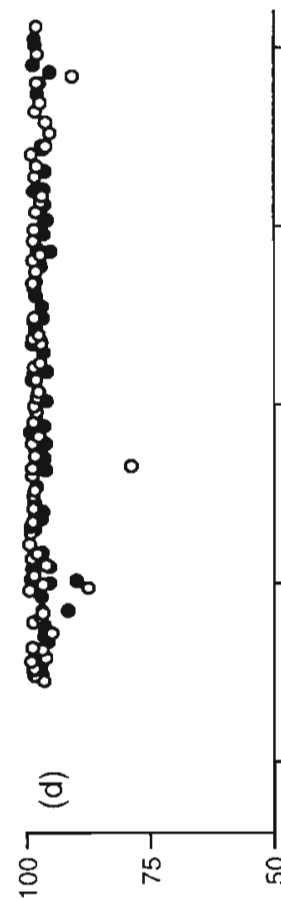

วouว6ıวuqns \%

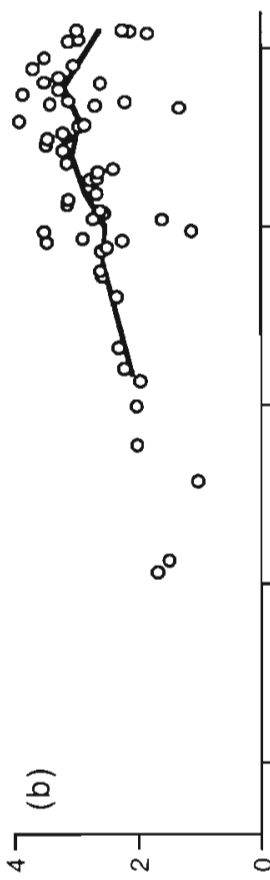

$(1-4 \cdot u x)$ pəods

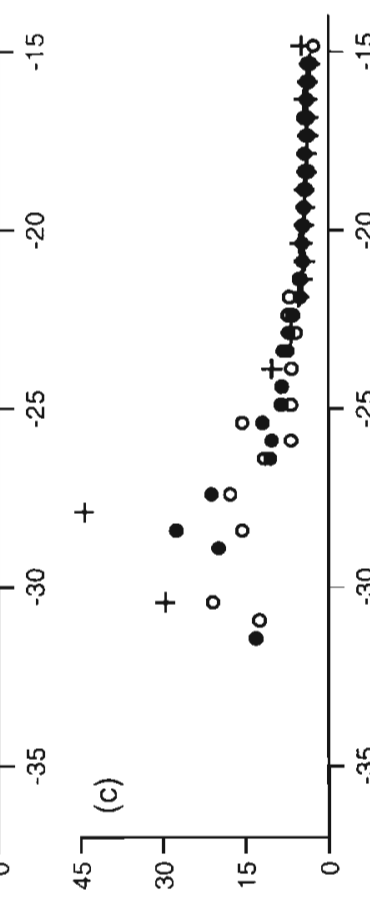

(su!m) әэuə6ิəəuqns to uo!tednp ueaw

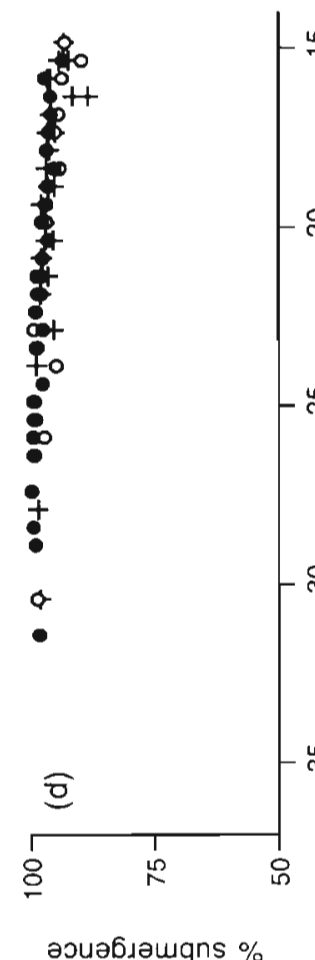

ววuวธฝอแqns \% 

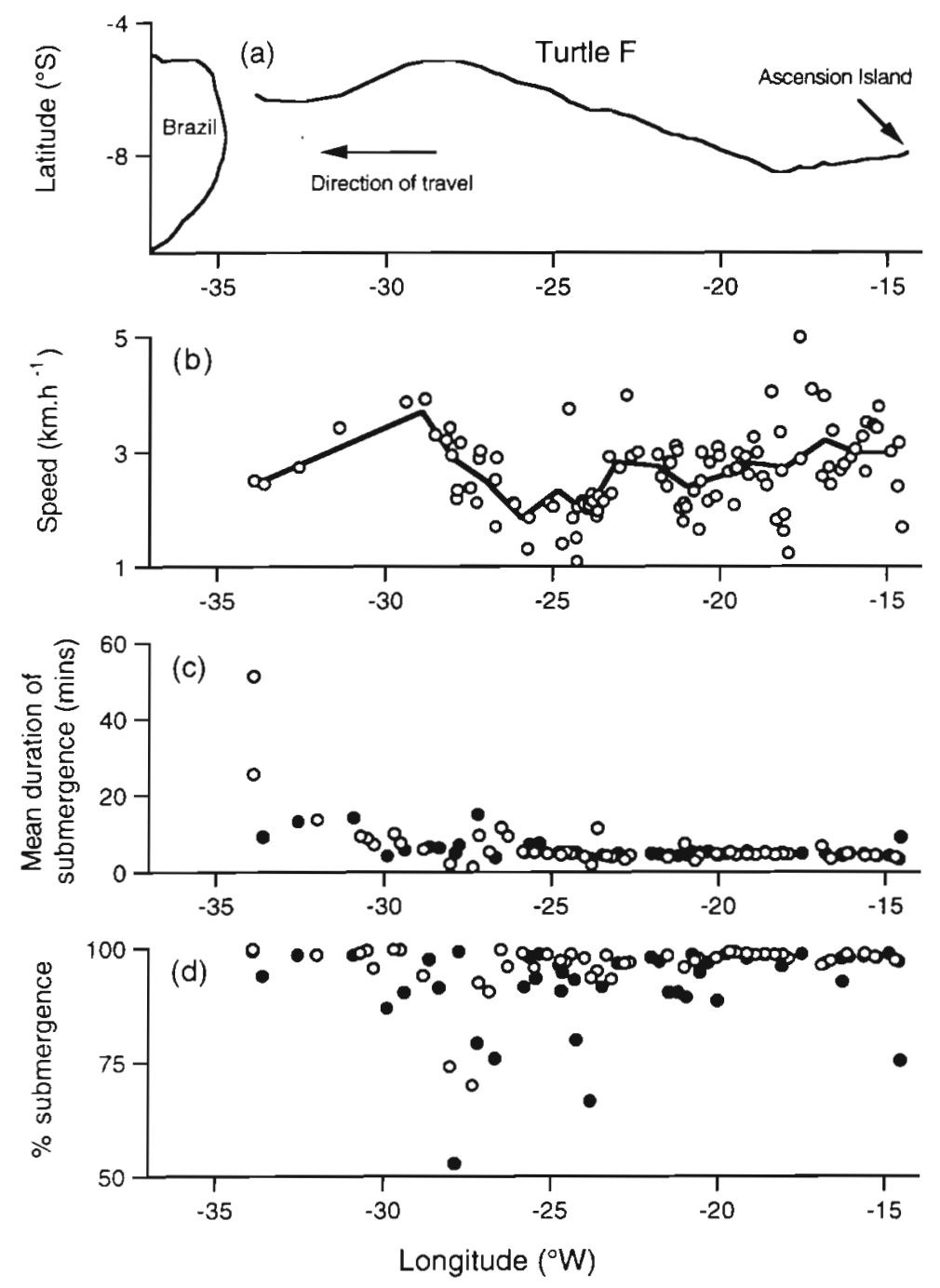

Fig. 10. Turtle F. Legend as in Figs. 6 \& 7

\section{Speed of travel}

Although the calculated speeds of travel showed a high degree of variability (Figs. 6 to 10), some general trends were evident. All the turtles departed from Ascension Island with a speed of around $3 \mathrm{~km} \mathrm{~h}^{-1}$. For example, between $14.5^{\circ}$ and $18.5^{\circ} \mathrm{W}$ all 5 turtles followed a similar WSW course, and over this region there was no significant difference between their speeds (Table 2, ANOVA, $F_{4,109}=$ $0.3, p=0.90$ ). As the turtles moved westwards from Ascension Island there was a general tendency for their speed of travel to decline. This tendency is clearly seen in Fig. 11 which shows how, for the 4 turtles which maintained very similar courses over the first $1000 \mathrm{~km}$, there was a linear decline in their mean speed between $14.5^{\circ}$ and $24.5^{\circ} \mathrm{W}$.
For 3 of the individuals (Turtles B, C and F) that turned and headed WNW, the speed of travel subsequently increased. For the other 2 individuals (Turtles D and E) that maintained more southerly routes, the speed of travel continued to decline during the migration until data from these transmitters ceased (Figs. 6 to 10). When all the data for the post-nesting migrations were considered there was a significant inter-individual variation in speed of travel, with Turtle E travelling markedly slower than the others (Table 2, ANOVA, $\left.F_{4,465}=173, \mathrm{p}<0.001\right)$.

\section{Ocean currents}

Model results for trajectories starting in May, June and July were effectively identical. Fig. 11c shows the modelled current speed moving WSW from Ascension Island for a particle released at $7^{\circ} 30^{\prime} \mathrm{S}, 15^{\circ} 00^{\prime} \mathrm{W}$, the closest model grid point to Ascension Island, during the middle of May. Moving WSW from Ascension Island, it is evident that between $15^{\circ}$ and $25^{\circ} \mathrm{W}$ the current speed declines from about 0.45 to $0.15 \mathrm{~km} \mathrm{~h}^{-1}$.

\section{DISCUSSION}

Examination of the submergence behaviour of marine animals can lead to inferences about the physiological adaptations to diving (e.g. Fedak \& Thompson 1993) and the levels and types of activity (foraging, travelling, etc.) (e.g. Le Boeuf et al. 1993). This area has been well developed in the study of marine mammals, particularly pinnipeds, through the use of time-depth recorders (TDRs) which constantly log the depth, allowing dive profiles to be reconstructed and, more recently, through the use of TDRs interfaced to satellite transmitters (e.g. Martin et al. 1993). In contrast, for sea turtles relatively little is known of natural dive patterns and the use of

Table 2. Mean swimming speed $\left(\mathrm{km} \mathrm{h}^{-1}, \pm 1 \mathrm{SE}\right)$ recorded for 5 turtles (1) between $14.5^{\circ} \mathrm{W}$ and $18.5^{\circ} \mathrm{W}$ and (2) throughout the post-nesting migration

\begin{tabular}{|lcc|}
\hline Turtle id & $14.5^{\circ} \mathrm{W}$ to $18.5^{\circ} \mathrm{W}$ & $\begin{array}{c}\text { Throughout post-nesting } \\
\text { migration }\end{array}$ \\
\hline $\mathrm{B}$ & $3.01( \pm 0.08)$ & $2.93( \pm 0.05)$ \\
$\mathrm{C}$ & $2.89( \pm 0.22)$ & $2.58( \pm 0.09)$ \\
$\mathrm{D}$ & $3.00( \pm 0.11)$ & $2.70( \pm 0.09)$ \\
$\mathrm{E}$ & $2.82( \pm 0.22)$ & $2.09( \pm 0.08)$ \\
$\mathrm{F}$ & $3.00( \pm 0.15)$ & $2.65( \pm 0.07)$ \\
\hline
\end{tabular}



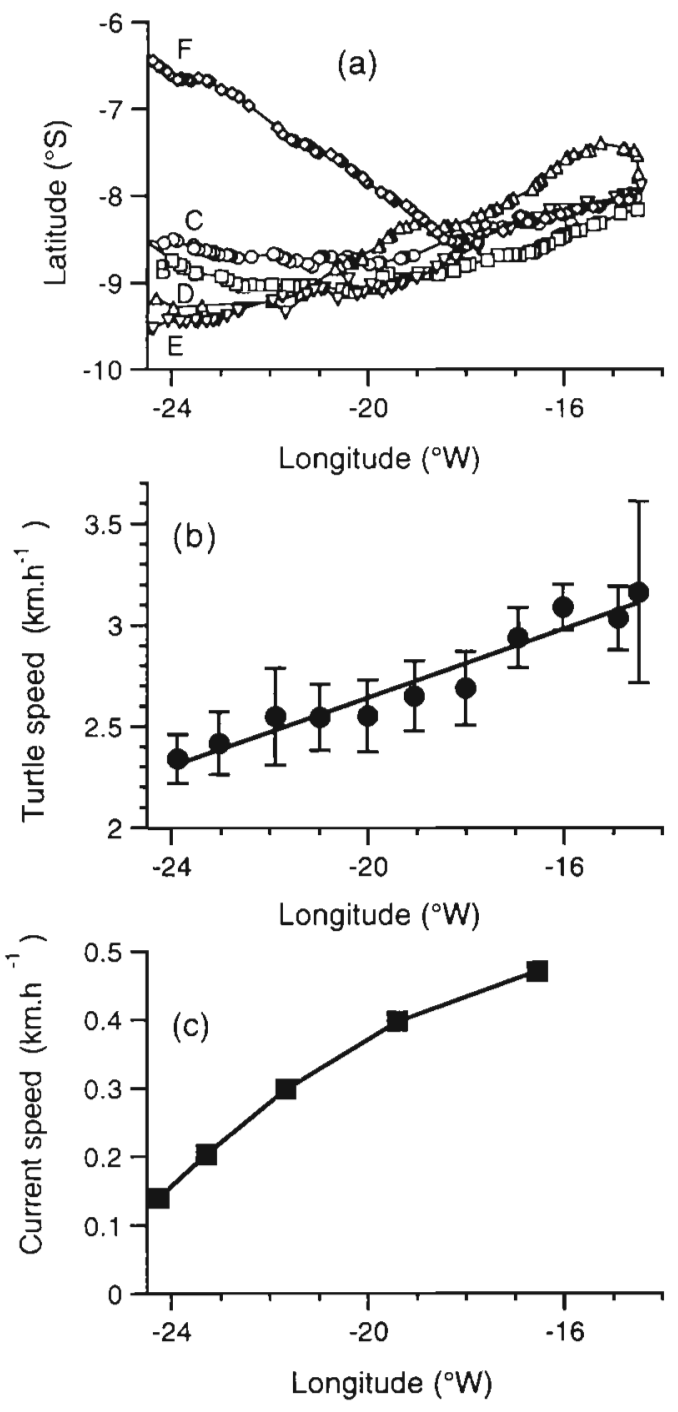

Fig. 11. (a) Initial courses followed by 5 turtles during their departure from Ascension Island. (b) The mean speed of travel $\left(\mathrm{km} \mathrm{h}^{-1}, \pm 1 \mathrm{SE}\right.$ ) for 4 individuals (Turtles $\mathrm{B}, \mathrm{C}, \mathrm{D}$ and E) in relation to longitude ( Each point represents the mean value of speed measurements per degree of longitude. Speed $\left(\mathrm{km} \mathrm{h}^{-1}\right)=4.34+0.0850$ longitude. $\left(F_{1,9}=132, \mathrm{p}<0.001, \mathrm{r}^{2}=\right.$ 0.94). (c) Results from the Global Isopycnic Model (GIM) showing the modelled speed of the surface current as it moves WSW from Ascension Island. The model was run with a release time in the middle of May and a release point at $7^{\circ} 30^{\prime} \mathrm{S}, 15^{\circ} 00^{\prime} \mathrm{W}$ (the closest model grid point to Ascension Island). We determined the current speed from the difference in position of the modelled mixed layer between the start and end of each month. This speed is plotted against the mean

longitude of the modelled mixed layer during that month

TDRs and satellite transmitters to examine diving behaviour is still in its infancy (Lutcavage \& Lutz 1997).

Between the inter-nesting period and the post-nesting migration, there was a clear dichotomy in the submergence behaviour of green turties nesting on Ascension Island, with submergences tending to be shorter during the post-nesting migration and longer during the inter-nesting period. As a consequence of the longer submergences during the inter-nesting period, the rate at which locations were provided by the Argos system was low compared to that during migration. This interaction between the performance of satellite transmitters and the behaviour of sea turtles has been noted before (Plotkin 1998), with the consistent pattern being that the Argos system is of limited use for identifying inter-nesting movements (Hays et al. 1991, Plotkin 1998), but allows post-nesting migrations to be accurately charted (Papi \& Luschi 1996)

The limited location data provided during the internesting period suggest that, at this time, the turtles generally stay within a few $\mathrm{km}$ of their nesting beach. Similarly, short duration ( $<38 \mathrm{~h})$ tracking experiments at Ascension Island, involving floats attached to turtles with $20 \mathrm{~m}$ lines, have shown that females tend to remain close to shore (Mortimer \& Portier 1989).

When sea turtles conduct dives of long duration in shallow coastal sites, these dives are frequently associated with resting on the sea floor; furthermore, there may be a strong diel periodicity with resting bouts occurring more at night (van Dam \& Diez 1996 Minamikawa et al. 1997). Both the duration of the submergences during the inter-nesting period and the diel signal in dive duration, therefore, point to the turtles being more quiescent at this time compared to during the migration from Ascension Island to South America.

As well as resting on the sea bed, marine turtles might also rest by basking on the surface. Since the prevailing current from Ascension Island, the South Atlantic Equatorial Current (SAEC), flows WSW, turtles might simply bask on the surface at the end of the nesting season and be carried passively back towards South America. Turtles would be expected to minimise their overall cost of transport between Ascension Island and South America. The metabolic rate of turtles, as with other animals, increases as a function of their activity (Prange 1976), and so by simply basking on the surface turtles might minimise their metabolic rate. However, the cost of completing the migration is unlikely to be a simple function of the instantaneous metabolic rate during the journey, since by moving slowly it will take longer for turtles to reach South America. In addition, by travelling slowly, turtles would delay the date on which they arrived at their feeding grounds and started to feed and replenish their fat reserves. In studies with immature $(0.25$ to $0.9 \mathrm{~kg}$ ) green turtles the metabolic rate has been measured over speeds ranging from 0 to $0.4 \mathrm{~m} \mathrm{~s}^{-1}$ (Prange 1976). Using the empirical relationship between metabolic rate and swimming speed, it was shown that the minimum cost of transport occurred at an intermediate swimming speed (Prange 1976). If the form of relation- 
ship between metabolic rate and swimming speed is the same for adult green turtles (the absolute values are immaterial in the following arguments) then, regardless of the speed of the current, the minimum cost of transport will be achieved at an intermediate swimming speed and not by swimming as fast as possible or by passively drifting. On this basis it would be predicted that adult turtles should not drift passively as they return from Ascension Island to South America. Our results are consistent with this prediction as they show that, first, migrating turtles do not bask for long periods at the sea surface and, second, since their speed of travel is much greater than the speed of the prevailing current, they do not simply drift passively while they are submerged.

Although basking has been observed in marine turtles in certain instances (Sapsford \& Van der Riet 1979), it is generally very rare, as evidenced in both the dive profiles recorded by attaching TDRs (e.g. Sato et al. 1995) and in the high level of submergence recorded by satellite transmitters (e.g. Renaud \& Carpenter 1994, Gitschlag 1996). While basking may provide a thermoregulatory role in freshwater turtles, allowing them to raise their body temperature (Spotila et al 1984), the implication is that basking is not widely used by marine turtles.

During migration, 3 of the turtles showed a clear diel pattern of submergence. This pattern is probably linked to their diel cycle of moving faster during the day and slower at night (Luschi et al. 1998). The inference is that the turtles do not always migrate with an unwavering effort, but that during the night they may slow down and make slightly longer dives. The variation in submergence behaviour between the 5 turtles was marked. For example, one turtle (Turtle B) maintained submergences of short duration throughout migration with a clear diel component; for another (Turtle C), there was a restricted period during the middle of migration when submergences of long duration were undertaken; for another (Turtle D) the duration of submergences gradually lengthened as migration progressed; while for another (Turtle E) submergences of long duration were conducted at night throughout migration. The significance of this interindividual variation is, as yet, unclear. It would appear that long submergences during migration were not associated with changes in course. For example, while the course followed by Turtle B changed distinctly during migration, submergence behaviour remained very consistent, while for turtle $C$ the long submergences conducted between 26 to $28^{\circ} \mathrm{W}$ were not associated with any clear course change. It would appear, therefore, that long submergences during migration are not part of the turtles' navigational mechanism. Also, green turtles, being herbivorous, are thought not to feed during the migration (Carr et al. 1974), and so longer submergences are presumably not associated with feeding. In the same way that the duration of submergences seems to be linked to levels of activity when the inter-nesting and migration periods are compared and when day/night patterns are considered, it may be that bouts of long submergences during migration are similarly associated with periods of less activity.

The SAEC undoubtedly plays a major role in structuring the ecology of the green turtle population on Ascension Island. First, this current will disperse hatchlings from the island. Second, migrating females depart from Ascension Island within the SAEC (Luschi et al. 1998), which supports the suggestion that the current may play a role in the navigation and orientation of the turtles, possibly through an odour plume that emanates from the island (Koch et al. 1969). Third, the SAEC may influence the speed of travel for migrating turtles. Our observations provide evidence for this third role. While there was much intra-individual variability in the speed of travel, which may have been caused by the inaccuracies of the fixes, when results from the different turtles were pooled there was a very clear decrease in the speed of travel during the first $1000 \mathrm{~km}$ of migration, in line with the decrease in the speed of the prevailing current. While the overall reduction in the turtles' speed between $14.5^{\circ}$ and $24.5^{\circ} \mathrm{W}$ was about $0.8 \mathrm{~km} \mathrm{~h}^{-1}$, the modelled decline in the current speed was only about $0.3 \mathrm{~km} \mathrm{~h}^{-1}$. This difference may partly reflect the properties of the GIM. As we have discussed before (Hays \& Marsh 1997), such numerical models probably give a good representation of mean current directions and the relative changes in current speed. However, to ensure computational stability, the relatively coarse horizontal resolution of these models necessitates a level of viscosity that leads to the magnitude of the modelled currents being only about $50 \%$ of the true values. Viewed in this light, the reduction in the speed of the SAEC can largely explain the reduction in the turtles' speed over the first $1000 \mathrm{~km}$. During the initial stages of migration, the turtles' speed was around $3 \mathrm{~km} \mathrm{~h}^{-1}$ and there was little inter-individual variation. This speed is higher than for green turtles migrating in the South China Sea, where values of $2.2,2.5,1.7$ and $1.7 \mathrm{~km} \mathrm{~h}^{-1}$ have been recorded for different individuals (Luschi et al. 1996). Clearly, the SAEC will contribute to the higher initial speeds of travel for Ascension Island turtles. After this initial decrease in speed, 3 of the turtles subsequently speeded up as they turned and headed WNW It may be significant that Turtle $E$, which had the slowest overall speed, also followed the most southerly course, taking it into an area where the westward component of the SAEC drops markedly (Luschi et al. 1998). The interaction between migration be- 
haviour and the prevailing physical oceanography appears to be very strong for Ascension Island turtles and this interaction clearly needs to be considered when examining the migration of other populations.

Acknowledgements. We are especially grateful to His Honour Roger Huxley, Administrator of Ascension Island, and to W. Wilkie, Vice-Administrator, for permission to work at the island and for their encouragement and welcome during our stay. We also wish to thank E. Zambianchi (IUN Naples) and S. Stutzer (Institut für Meereskunde Kiel) for their precious help in obtaining information about oceanic currents, S. Ghione (CNR Pisa) for his help in the field, and C. Vieitas and the people of the Pro-Tamar Foundation (Brazil), R. Mencacci, L. Morelli and E. Crosio (Univ. of Pisa), for their technical assistance. This work was supported by the Department of the Environment. Transport and Regions (DETR, UK) within their Darwin Initiative for the Survival of Species programme, the Natural Environment Research Council (NERC, UK), the Italian CNR and the Accademia Nazionale dei Lincei. The Global Isopycnic Model (GIM) used here was set up and run at the Southampton Oceanography Centre by Alex Megann and Adrian New.

\section{LITERATURE CITED}

Carr A, Ross P, Carr S (1974) Inter-nesting behaviour of the green turtle, Chelonia mydas, at a mid-ocean island breeding ground. Copeia 1974:703-706

Dietz $R$, Heidejorgensen MP (1995) Movements and swimming speed of narwhals, Monodon monoceros, equipped with satellite transmitters in Melville Bay, northwest Greenland. Can J Zool 73:2106-2119

Fedak MA, Thompson D (1993) Behavioural and physiological options in diving seals. Symp Zool Soc Lond 66: $333-348$

Gitschlag GR (1996) Migration and diving behavior of Kemp's ridley (Garman) sea turtles along the U.S. southeastern Atlantic coast. J Exp Mar Biol Ecol 205:115-135

Hays GC, Marsh R (1997) Estimating the age of juvenile loggerhead sea turtles in the North Atlantic. Can J Zool 75: $40-46$

Hays GC, Webb PI, Hayes JP, Priede IG, French J (1991) Satellite tracking of a loggerhead turtle (Caretta caretta) in the Mediterranean. J Mar Biol Assoc UK 71:743-746

Hull CL, Hindell MA, Michael K (1997) Foraging zones of royal penguins during the breeding season, and their association with oceanographic features. Mar Ecol Prog Ser 153:217-228

Jouventin P, Weimerskirch H (1990) Satellite tracking of wandering albatrosses. Nature 343:746-748

Jouventin P, Capdeville D, Cuenotchaillet F, Boiteau C (1994) Exploitation of pelagic resources by a nonflying seabirdsatellite tracking of the king penguin throughout the breeding cycle. Mar Ecol Prog Ser 106:11-19

Koch AL, Carr A, Ehrenfeld DW (1969) The problem of open sea navigation: the migration of the green turtle Chelonia mydas to Ascension Island. $J$ Theor Biol 22:163-179

Le Boeuf BJ, Crocker DE, Blackwell SB, Morris PA, Thorson PH (1993) Sex differences in diving and foraging behaviour of northern elephant seals. Symp Zool Soc Lond 66:149-178

Luschi P, Papi F, Liew HC, Chan EH, Bonadonna F (1996) Long-distance migration and homing after displacement

Editorial responsibility: Otto Kinne (Editor),

Oldendorf/Luhe, Germany in the green turtle (Chelonia mydas): a satellite tracking study. J Comp Physiol 178A:447-452

Luschi P, Hays GC, Del Seppia C, Marsh R, Papi F (1998) The navigational feats of green sea turtles migrating from Ascension Island investigated by satellite telemetry. Proc R Soc Lond B 265:2279-2284

Lutcavage ME, Lutz PL (1997) Diving physiology. In: Lutz PL, Musick JA (eds)The biology of sea turtles. CRC Press, Boca Raton, p 277-296

Marsh R, Nurser AJG, Megann AP, New AL (in press) Water mass transformation in the Southern Ocean of a Global Isopycnal Coordinate GCM. J Phys Oceanogr

Martin AR, Smith TG, Cox OP (1993) Studying the behaviour and movements of high Arctic belugas with satellite telemetry. Symp Zool Soc Lond 66:195-210

Mate BR, Nieukirk SL, Kraus SD (1997) Satellite-monitored movements of the northern right whale. J Wildl Manag 61: 1393-1405

McConnell BJ, Fedak MA (1996) Movements of southern elephant seals. Can J Zool 74:1485-1496

Minamikawa S, Naito Y, Uchida I (1997) Buoyancy control and diving behaviour of the loggerhead turtle, Caretta caretta. J Ethol 15:109-118

Mortimer JA, Carr A (1987) Reproduction and migrations of the Ascension Island green turtle (Chelonia mydas). Copeia 1987:103-113

Mortimer JA, Portier KM (1989) Reproductive homing and inter-nesting behavior of the green turtle (Chelonia mydas) at Ascension Island, South Atlantic Ocean. Copeia 1989:962-977

Papi F, Luschi P (1996) Pinpointing 'Isla Meta': the case of sea turtles and albatrosses. J Exp Biol 199:65-71

Plotkin PT (1998) Interaction between behavior of marine organisms and the performance of satellite transmitters: A marine turtle case study. Mar Tech Soc J 32:5-10

Plotkin PT, Byles RA, Rostal DC, Owens DW (1995) Independent versus socially facilitated oceanic migrations of the olive ridley, Lepidochelys olivacea. Mar Biol 122:137-143

Prange HD (1976) Energetics of swimming of a sea turtle. J Exp Biol 64:1-12

Read AJ, Westgate AJ (1997) Monitoring the movements of harbour porpoises (Phocoena phocoena) with satellite telemetry. Mar Biol 130:315-322

Renaud ML, Carpenter JA (1994) Movements and submergence patterns of loggerhead turtles (Caretta caretta) in the Gulf of Mexico determined through satellite telemetry Bull Mar Sci 55:1-15

Sapsford CW, Van der Riet M (1979) Uptake of solar radiation by the sea turtle, Caretta caretta, during voluntary surface basking. Comp Biochem Physiol 63:471-474

Sato K, Sakamoto W, Matsuzawa Y, Tanaka H, Minamikawa S, Naito Y (1995) Body temperature independence of solar radiation in free-ranging loggerhead turtles, Caretta caretta, during internesting periods. Mar Biol 123: $197-205$

Spotila JR, Foley RE, Schubauer JP, Semlitsch RD, Crawford KM, Standora EA, Gibbons JW (1984) Opportunistic behavioral thermoregulation of turtles, Pseudemys scrip$t a$, in response to micro-climatology of a nuclear reactor cooling reservoir. Herpetologica 40:299-308

Thompson D, Hiby AR, Fedak MA (1993) How fast should I swim? Behavioural implications of diving physiology. Symp Zool Soc Lond 66:349-368

van Dam RP, Diez CE (1996) Diving behavior of immature hawksbills (Eretmochelys imbricata) in a Caribbean cliffwall habitat. Mar Biol 127:171-178

Submitted: December 21, 1998; Accepted: July 5, 1999

Proofs received from author(s): November 8, 1999 